\title{
Community Characteristics Analysis of Eukaryotic Microplankton via ITS Gene Metabarcoding Based on Environmental DNA in Lower Reaches of Qiantang River, China
}

\author{
Aiju Zhang1, Jun Wang1, Yabin Hao', Shanshi Xiao1, Wei Luo1, Ganxiang Wang2, Zhiming Zhou1 \\ ${ }^{1}$ Agriculture Ministry Key Laboratory of Healthy Freshwater Aquaculture, Key Laboratory of Freshwater Aquaculture Genetic and \\ Breeding of Zhejiang Province, Zhejiang Research Center of East China Sea Fishery Research Institute, Zhejiang Institute of \\ Freshwater Fisheries, Huzhou, China \\ ${ }^{2}$ Pinghu Fisheries Technology Promotion Center, Pinghu, China \\ Email: zjhz-zzm@163.com
}

How to cite this paper: Zhang, A.J., Wang, J., Hao, Y.B., Xiao, S.S., Luo, W., Wang, G.X. and Zhou, Z.M. (2021) Community Characteristics Analysis of Eukaryotic Microplankton via ITS Gene Metabarcoding Based on Environmental DNA in Lower Reaches of Qiantang River, China. Open Journal of Animal Sciences, 11, 105-124. https://doi.org/10.4236/ojas.2021.112009

Received: January 13, 2021

Accepted: March 30, 2021

Published: April 2, 2021

Copyright $\odot 2021$ by author(s) and Scientific Research Publishing Inc. This work is licensed under the Creative Commons Attribution International License (CC BY 4.0).

http://creativecommons.org/licenses/by/4.0/

\begin{abstract}
Eukaryotic microplankton plays an important role in water biotic community and in maintaining the stability of water ecosystems. Environmental DNA metabarcoding provides the opportunity to integrate traditional and emerging approaches to discover more new species, and develop molecular biotic indices that can be more rapidly, frequently, and robustly used in water quality assessments. In order to examine assemblages of eukaryotic microplankton in lower reaches of Qiantang River, ITS gene metabarcoding technology based on environmental DNA was carried out. As a result, various species of phytoplankton, fungi and zooplankton were annotated on. More phylum, classes and specieses of eukaryotic phytoplankton and zooplankton were found after compared communities taxa based on metabarcoding with that obtained from morphological examination. Nevertheless, Chlorophyceae was the most common assemblage both identified by using these two methods, also Mesocyclops leuckarti and Acanthocyclops bicuspidatus were both found to be the dominant species of Cyclopoida in the river. Additionally, the reads proportions of phytoplankton and zooplankton at the three freshwater sampling sites (Tonglu, Fuyang and Wenyan) decreased as temperature drop. Meanwhile, twenty classes of fungi were annotated on, of which the community characteristic was first researched in the river. There were significant spatial differences in values of Chaol index for eukaryotic microplankton. Cluster analysis and Non-metric multidimensional scaling ordination further
\end{abstract}


confirmed that the community composition of eukaryotic microplankton at class level for Jiashao-September sample had the most dissimilarity with the others.

\section{Keywords}

Microplankton, eDNA, Metabarcoding, ITS, Diversity, Qiantang River

\section{Introduction}

Eukaryotic microplankton is a group of plankton with particle sizes less than $20-\mu \mathrm{m}$ [1]. It plays an important role in water biotic community and in maintaining the stability of water ecosystems due to its important link in energy flow and material circulation [1]. As the basis of the food chain, analyzing its metacommunity structure is very important to assess the status and development tendency of an ecosystem [2].

Traditional practices for biological surveys of inland waters usually center on a common set of ecological indicators or indices/measurements of biodiversity [3], requiring many preparations, such as morphological taxonomic expertise, intact specimens and adequate time [4] [5]. Environmental DNA (eDNA) metabarcoding provides the opportunity to integrate traditional and emerging approaches to discover more new species [6] [7], and develop molecular biotic indices that can be more rapidly, frequently, and robustly used in water quality assessments [6] [8] [9]. So far, metabarcoding technology has been widely used for biodiversity monitoring in biological and environmental samples [10] [11] [12] [13]. Despite some limitations (each marker region might import some biases and the blast sequence database is incomplete), the practices of metabarcoding-based analysis for estimating diversity and relative abundance of taxonomic groups in aquatic systems will likely increase as technology improved [14].

Now, marker genes used for the analysis of plankton communities via eDNA metabarcoding often focuses on ribosomal DNA (rDNA), ribulose bisphosphate carboxylase large subunit gene ( $\mathrm{rbc} \mathrm{L}$ ) and cytochrome $\mathrm{C}$ oxidase subunit gene 1 (cox1) [8] [15] [16] [17] [18]. Among these, the internal transcribed spacer (ITS), as one gene fragment of rDNA, has been widely used due to its fast evolution and high specificity [17], and its relevant metabarcoding practices for the purpose of monitoring diversity of eukaryon communities mainly focused on soil, plant and marine systems [19] [20] [21] [22].

Here, an ITS metabarcoding assessing assemblages of eukaryotic microplankton were conducted. Specifically, ITS gene sequence analysis was performed on surface water samples collected from four sites in Qiantang River lower reaches (Zhejiang, China), an important freshwater fishing water used for drinking, electricity generation, flood control and recreation, in order to analyze the community diversity of eukaryotic microplankton in the section, to assess the 
utility of this approach for monitoring diversity of freshwater eukaryotic microplankton community. As a whole, this study provided a theoretical basis for further study on the function of eukaryotic microplankton in freshwater ecosystems.

\section{Materials and Methods}

\subsection{Water Sample Collection and Physic Chemical Analysis}

A total of eight water samples were collected in September and November 2019, at four separate sampling sites in Qiantang River lower reaches, including Tonglu, Fuyang, Wenyan and Jiashao sites, hereafter referred to as TL, FY, WY and JS separately (Figure 1). All sampling, filtering, and other equipments were sterilized before use.

$2 \mathrm{~L}$ of surface water was collected at a set time by boat from each site. Simultaneously, five environmental variables, such as transparency, salinity, water temperature (WT), $\mathrm{pH}$ and dissolved oxygen (DO), were measured in situ by using a secchi disk and a portable water quality detector (Hach, USA). For each

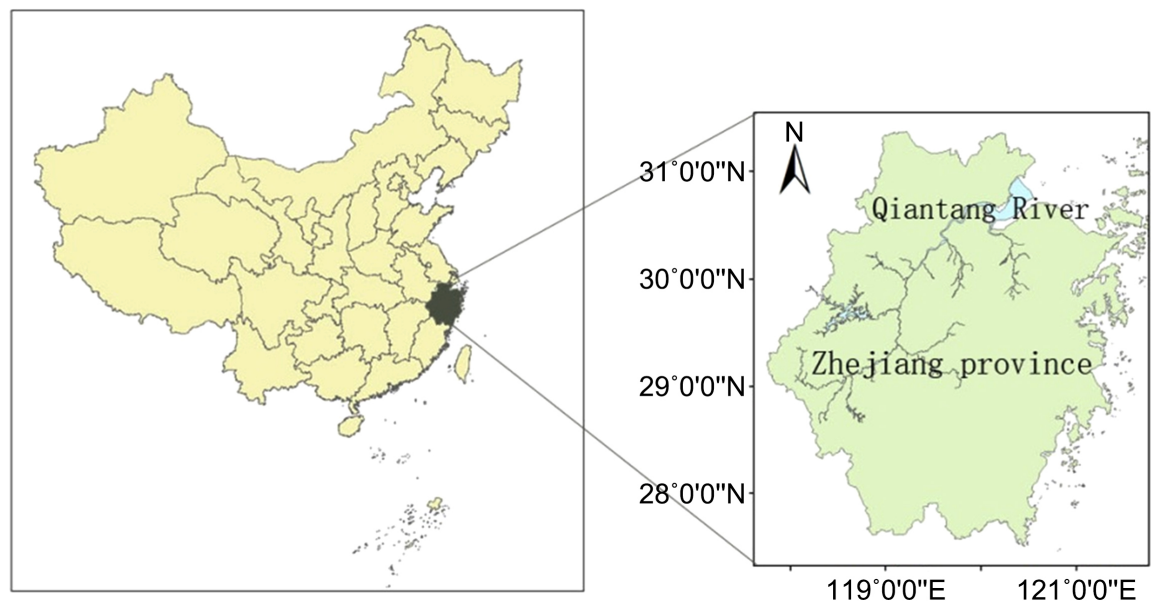

(a)

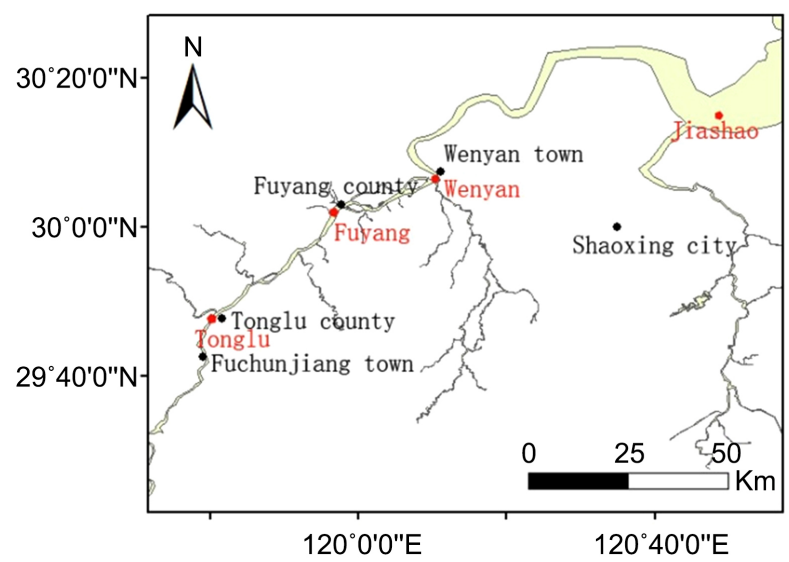

(b)

Figure 1. Map shows the study site. (a) The location of Qiantang River in Zhejiang province of China; (b) Sampling sites in Qiantang River lower reaches. The red dot represents the water sampling site, the black dot represents the local government seat. 
water sample, a $1.5 \mathrm{~L}$ water subsample was used to test six environmental variables immediately after transported to the laboratory within 24 hours at $4^{\circ} \mathrm{C}$, including Chemical oxygen demand (COD), Chlorophyll a (Chla), total nitrogen (TN), total phosphorus (TP), ammonium $\left(\mathrm{NH}_{4}-\mathrm{N}\right)$ and nitrate-nitrite $\left(\mathrm{NO}_{3}-\mathrm{N}\right)$, the recording of which were following the scheme of [23]. All environmental variables were measured in triplicate.

\subsection{DNA Sample Processing and High-Throughput Sequencing (HTS)}

For each water sample, a residual $500-\mathrm{mL}$ water subsample was then filtered through a $0.22-\mu \mathrm{m}$ cellulose acetate filter paper using a peristaltic pump in the field. Then, each paper was placed inside a commercial sterile centrifuge tube and stored in a container filled with liquid nitrogen until subsequent manipulations were performed. DNA was extracted from filters using EZNA water DNA kit (Omega, USA) following the manufacturer's protocol. The concentration and purity of DNA were determined using NanoDrop 2000c spectrophotometer (Thermo, USA), then followed by multiplex PCR using the universal primers for ITS belonging to eukaryotic mitochondrial DNA fragments, ITS-F (5'-GTGA ATCATCGARTC-3), ITS-R (5'-TCCTCCGCTTATTGAT-3') [22]. Each eDNA sample was subjected to PCRs in triplicate $\left[17.35 \mu \mathrm{L} \mathrm{dH_{2 }}\right.$ O, $2.5 \mu \mathrm{L} 10 \times$ PCR buffer, $0.15 \mu \mathrm{L} 5 \mathrm{U} / \mu \mathrm{L}$ Thermo scientific Taq DNA polymerase, $2 \mu \mathrm{L}$ dNTPs mix $(2.5 \mathrm{mM}), 1 \mu \mathrm{L}$ of each primer $(10 \mathrm{mM})$, and $1 \mu \mathrm{L}$ sample eDNA in a total volume of $25 \mu \mathrm{L}$ ]. PCR cycling parameters were as follows: $96^{\circ} \mathrm{C}$ for $3 \mathrm{~min}$, followed by 35 cycles of $96^{\circ} \mathrm{C}$ for $30 \mathrm{~s}, 50^{\circ} \mathrm{C}$ for $30 \mathrm{~s}$, and $72^{\circ} \mathrm{C}$ for $90 \mathrm{~s}$, with a final elongation step at $72^{\circ} \mathrm{C}$ continued for $7 \mathrm{~min}$. Negative control was conducted simultaneously. After subjecting the PCR products to $1 \%$ polyacrylamide gels (see Figure S1), the quantified, size-selected libraries were constructed and continuously diluted to a concentration suitable for sequencing. The libraries were finally sequenced on the Illumina MiSeq 2000 platform by following the manufacturer's protocols step by step.

\subsection{Phytoplankton Samples Collection and Treatment}

Phytoplankton samples were also simultaneously collected at the four sites. For phytoplankton counts, $1.0 \mathrm{~L}$ of water samples were sampled each time and preserved with $1 \%$ Lugol's iodine solution. Phytoplankton samples were concentrated to a final volume of $30 \mathrm{ml}$ after sedimentation for $48 \mathrm{~h}$. Thereafter, the taxa were verified and counted under $200 \times$ and $400 \times$ magnifications for at least 500 specimens [23]. The data were made to compare with that collected from ITS gene metabarcoding method.

\subsection{Bioinformatics and Sequencing Data Upload}

The raw sequencing FASTQ file was transformed to a FASTA file by the Fastx toolkit V0.0.1 [24]. Clean reads were gained after trimming the low quality se- 
quences and PCR chimeras by using Fqtrim V0.9.4

(http://ccb.jhu.edu/software/fqtrim/) and Vsearch 2.3.4 [25]. Vsearch 2.3.4 software continued to be utilized to cluster Operational taxonomic units (OTUs) at $97 \%$ cutoff of sequence similarity. Representative sequences of OUTs were assign to taxonomic groups against the NCBI Genbank by using Blast+ 2.6.0 at $80 \%$ cutoff of identity thresholds with over $80 \%$ matches and expect values less than 1e-5. The Sequencing data have been uploaded to NCBI Sequence Read Archive database, with accession numbers vary from SRR10800795 to SRR10800802.

\subsection{Date Analysis}

Three a-diversity indices, including Chaol estimators, Simpson index, and Shannon index, were calculated based on data obtained by metabarcoding monitoring. Additionally, Cluster analysis taken by group average method and Non-metric multidimensional scaling (NMDS) was employed to cluster samples in Primer 5.0 environment [26], of which species data were first transformed according to [27]. Additionally, basic data processing, drawing and statistical analyses (e.g. one-way ANOVA) were conducted using Excel 2007 and SPSS 16.0 software.

\section{Results}

\subsection{Environmental Characterization}

The results of environmental variables are showed in Table 1. WT showed significant differences between months. TN showed significant negative association with transparency at $\mathrm{p}<0.05$, with COD at $\mathrm{p}<0.01$, and significant positive association with TP at $\mathrm{p}<0.01$. In addition, NH4-N showed a significant positive association with TP and WT at $\mathrm{p}<0.05$. The values of TN: TP mass ratios were all higher than 7 in all sampling sites, indicating the research area was generally P-limited at the experimental period.

\subsection{Sequencing Analysis}

ITS gene metabarcoding yielded 67,469 - 129,150 raw reads, of which 55,687 112,832 clean reads were obtained after optimization, resulting in effective data rates varying from $64.1 \%$ to $88.8 \%$ (Table 2 ). The sequences clustered into a total of 5795 OTUs, varying from 706 to 1911 at an average of 1245 (Table 2). Meanwhile, the rarefaction curves of each sample all showed the observed species number flatted out as sequence increasing, indicating the amount of sequencing data at the $97 \%$ similarity threshold was sufficient to satisfy the assessment of species diversity.

\subsection{Community Structure Composition}

In total, Phytoplankton, fungi, zooplankton and other eukaryotes were annotated on after Blast. Five classes of eukaryotic phytoplankton were annotated on, 
Table 1. Values of the eleven environmental variables from sampling sites.

\begin{tabular}{|c|c|c|c|c|c|c|c|c|c|c|c|}
\hline \multirow[b]{2}{*}{ Sample } & \multicolumn{5}{|c|}{ In situ } & \multicolumn{6}{|c|}{ In lab } \\
\hline & $\begin{array}{c}\mathrm{DO} \\
(\mathrm{mg} / \mathrm{L})\end{array}$ & $\mathrm{pH}$ & $\mathrm{WT}\left({ }^{\circ} \mathrm{C}\right)$ & Salinity & $\begin{array}{c}\text { Transparency } \\
(\mathrm{cm})\end{array}$ & $\begin{array}{l}\text { Chl a } \\
(\mu \mathrm{g} / \mathrm{L})\end{array}$ & $\begin{array}{l}\text { COD } \\
(\mathrm{mg} / \mathrm{L})\end{array}$ & $\begin{array}{c}\mathrm{TP} \\
(\mathrm{mg} / \mathrm{L})\end{array}$ & $\begin{array}{c}\mathrm{TN} \\
(\mathrm{mg} / \mathrm{L})\end{array}$ & $\begin{array}{l}\mathrm{NH}_{4}-\mathrm{N} \\
(\mathrm{mg} / \mathrm{L})\end{array}$ & $\begin{array}{l}\mathrm{NO}_{3}-\mathrm{N} \\
(\mathrm{mg} / \mathrm{L})\end{array}$ \\
\hline TL-A & 6.66 & 7.28 & 24.8 & - & 170 & 1.77 & 17.00 & 0.05 & 2.11 & 0.33 & 1.25 \\
\hline TL-B & 7.21 & 7.38 & 18.0 & - & 300 & 0.40 & 14.00 & 0.06 & 1.73 & 0.11 & 1.51 \\
\hline FY-A & 6.53 & 7.37 & 26.3 & - & 75 & 3.21 & 15.00 & 0.05 & 1.93 & 0.32 & 1.26 \\
\hline FY-B & 7.83 & 7.35 & 18.3 & - & 250 & 0.95 & 14.00 & 0.06 & 1.51 & 0.12 & 1.32 \\
\hline WY-A & 8.20 & 7.29 & 27.5 & - & 65 & 6.97 & 17.00 & 0.06 & 2.00 & 0.32 & 1.36 \\
\hline WY-B & 8.25 & 7.48 & 18.7 & - & 110 & 5.52 & 8.00 & 0.04 & 1.88 & 0.42 & 1.28 \\
\hline JS-A & 7.29 & 7.79 & 30.3 & + & 5 & 3.82 & 2.02 & 0.28 & 3.77 & 0.89 & 1.68 \\
\hline JS-B & 9.33 & 7.95 & 18.5 & + & 10 & 2.94 & 2.76 & 0.29 & 3.46 & 0.12 & 2.89 \\
\hline
\end{tabular}

A: the "September" sample; B: the "November" sample. Hereinafter inclusive; +: salinity measured; -: no salinity measured.

Table 2. Temporal and spatial variation of indices based on ITS gene metabarcoding data.

\begin{tabular}{|c|c|c|c|c|c|c|c|c|}
\hline & Sep. & Nov. & Sep. & Nov. & Sep. & Nov. & Sep. & Nov. \\
\hline & \multicolumn{2}{|c|}{$\mathrm{TL}$} & \multicolumn{2}{|c|}{ FY } & \multicolumn{2}{|c|}{ WY } & \multicolumn{2}{|c|}{ JS } \\
\hline Number of raw reads & 86,859 & 87,871 & 72,481 & 83,729 & 67,469 & 73,525 & 68,724 & 129,150 \\
\hline Number of clean reads & 55,687 & 75,178 & 60,425 & 73,516 & 55,784 & 65,278 & 59,221 & 112,832 \\
\hline effective data rate (\%) & 64.1 & 85.6 & 83.4 & 87.8 & 82.7 & 88.8 & 86.2 & 87.4 \\
\hline Number of OTUs & 1911 & 1370 & 1485 & 978 & 1641 & 1130 & 706 & 744 \\
\hline Reads abundance for phytoplankton (\%) & 21.8 & 4.9 & 40.9 & 3.7 & 45.7 & 2.2 & 3.6 & 27.0 \\
\hline Reads abundance for zooplankton (\%) & 0.3 & 0.1 & 0.3 & 0.0 & 0.1 & 0.1 & 0.0 & 0.1 \\
\hline Reads abundance for fungi (\%) & 9.7 & 10.2 & 4.7 & 3.8 & 3.1 & 22.4 & 22.2 & 43.7 \\
\hline Reads abundance for other eukaryotes (\%) & 0.7 & 0.1 & 0.1 & 0.0 & 0.2 & 0.1 & 0.0 & 0.2 \\
\hline Reads abundance for unclassified (\%) & 89.3 & 89.6 & 94.9 & 96.2 & 96.6 & 77.4 & 77.8 & 56 \\
\hline Shannon index based on metabarcoding & 7.7 & 5.1 & 7.0 & 4.6 & 7.6 & 6.0 & 3.3 & 6.1 \\
\hline Simpson index based on metabarcoding & 1.0 & 0.9 & 1.0 & 0.8 & 1.0 & 0.9 & 0.7 & 1.0 \\
\hline Chaol index based on metabarcoding & 2063.2 & $1,494.1$ & 1666.4 & 1077.2 & 1813.8 & 1288.3 & 810.0 & 684.9 \\
\hline
\end{tabular}

Sep.: September; Nov.: November.

in which Chlorophyceae, Trebouxiophyceae and Cryptophyceae had more reads abundance (Figure 2(a)). Genera Chlamydomonas, Micractinium, Chlorella, Crucigenia, Cryptomonas, Actinastrum, Gonium, Dictyosphaerium and Compactochlorella were the common phytoplankton, most of which belong to phylum Chlorophyta, except Cryptomonas which belongs to phylum Cryptophyta. Meanwhile, three classes of zooplankton, including Ciliatea (Protozoa), Maxillopoda (Arthropoda) and Hydrozoa (Cnidaria), were annotated on, and the first two classes were the common zooplankton assemblages (Figure 2(b)). Further- 
more, twenty classes of fungi were annotated on, Dothideomycetes, Sordariomycetes, Eurotiomycetes and Tremellomycetes were the common classes (Figure 2(c)). However, the common classes of fungi in JS-A sample were others, such as Malasseziomycetes, Agaricostilbomycetes, Ustilaginomycetes and Wallemiomycetes.

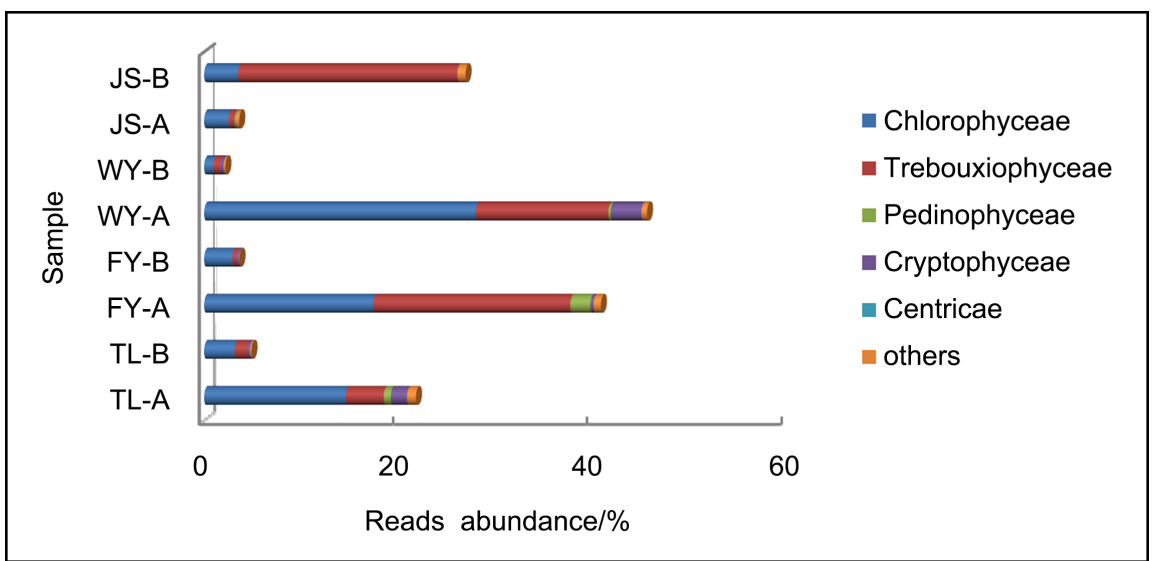

(a)

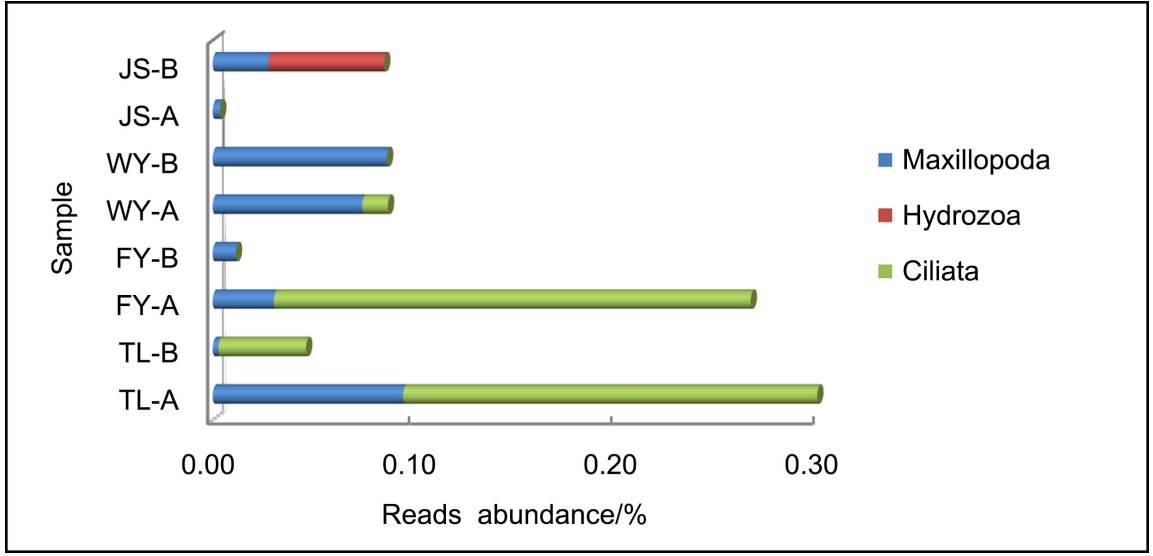

(b)

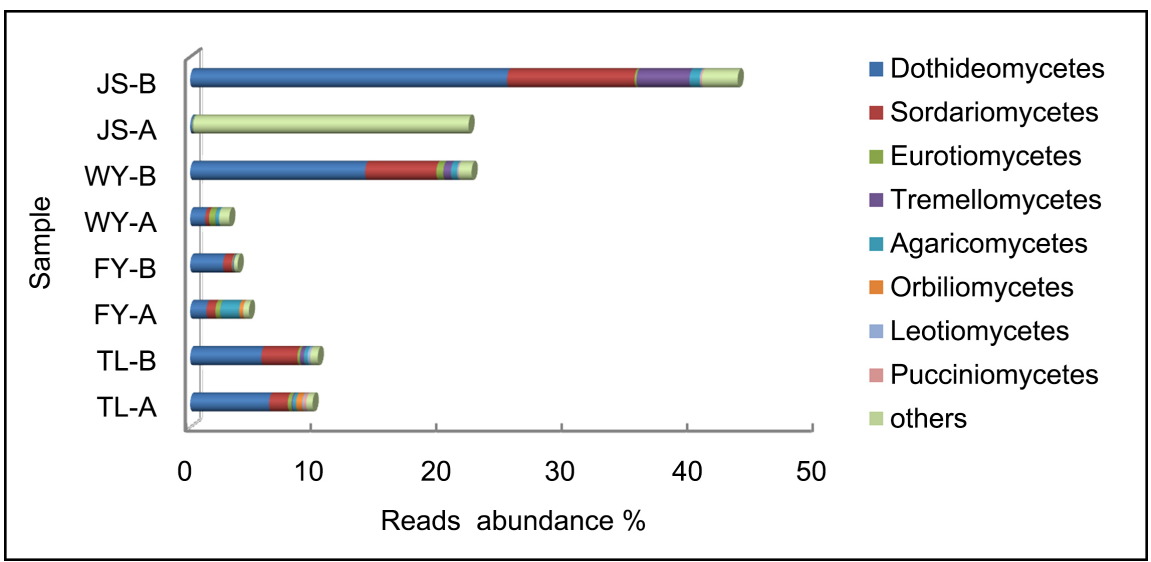

(c)

Figure 2. Reads abundance of eukaryotic microplankton (phytoplankton (a), zooplankton (b) and fungi (c)) based on ITS gene metabarcoding in eight samples at class level. 


\subsection{Seasonal Dynamics of Communities}

Overall, the total reads of ITS annotated on eukaryotic microplankton in September was higher than that in November. The dominant assemblage in TL, FY and WY sites in September was phytoplankton, contributing $21.8 \%, 40.9 \%$ and $45.7 \%$ of the total reads respectively, followed by fungi $(9.7 \%, 4.70 \%$ and $3.1 \%$, respectively) and zooplankton $(0.3 \%, 0.3 \%$ and $0.1 \%$, respectively), however, the result in JS site was different, in which fungi was dominant (Table 2; Figure 3). Nevertheless, fungi changed to be the dominant in November in all four sampling sits with $10.2 \%$ of total reads in TL, 3.8\% in FY, $22.4 \%$ in WY and $43.7 \%$ in JS site, and phytoplankton became to be the secondary assemblages simultaneously (Table 2; Figure 3). Combined with water temperature and salinity condition, the reads proportions of phytoplankton and zooplankton in the three freshwater sampling sites (TL, FY and WY) decreased as temperature drop, while fungi increased in majority of sites except FY. The reads abundance of phytoplankton and zooplankton at the estuarine site, JS, were fewer than the contemporaneous reads of three freshwater sites, and the reads of fungi were also opposite.

\subsection{Diversity Analysis of Eukaryotic Microplankton}

Significant spatial differences in values of Chaol index were deduced $(\mathrm{p}<0.05)$. However, Shannon and Simpson indexes showed no significant spatio-temporal differences. Generally, the three indexes in September at the freshwater sampling sites were all higher than that in November, which was a little different from that in JS sites (Table 2).

Eight samples were divided into two clusters at the $20 \%$ level, cluster for JS-A and cluster for the other seven samples, indicating that the microplankton class composition of JS-A had the least similar with that of the other samples (Figure 4(a)), which was also verified by using NMDS ordination method (Figure 4(b)).

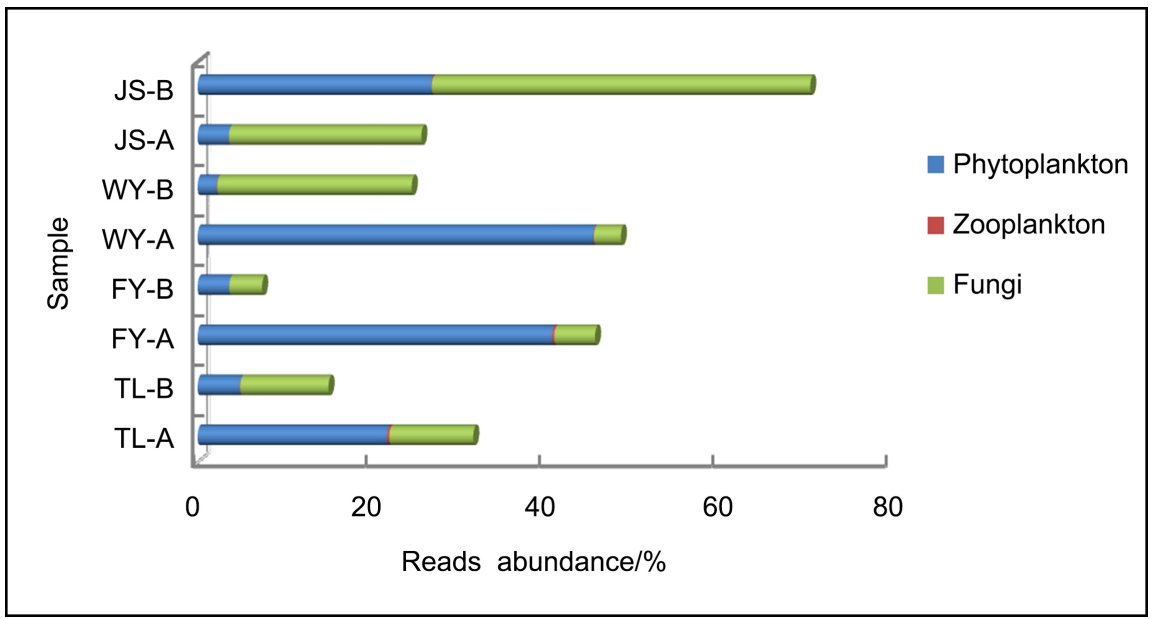

Figure 3. Reads abundance vibration of eukaryotic microplankton based on ITS gene metabarcoding in eight samples. 


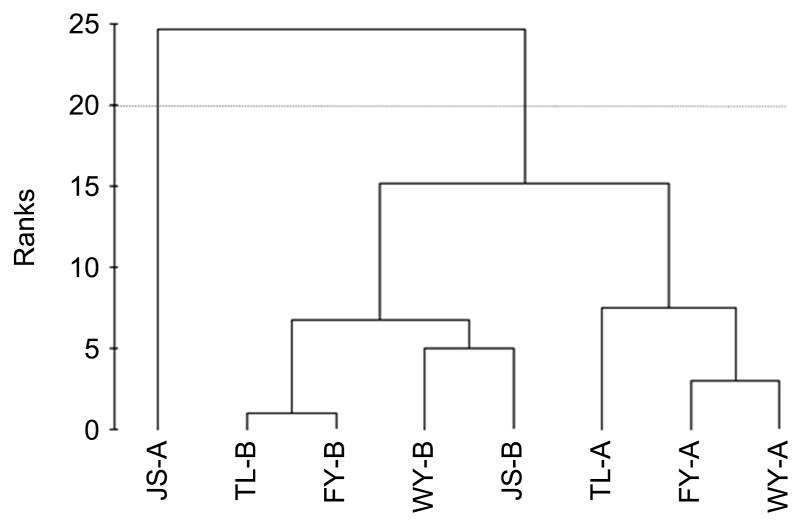

(a)

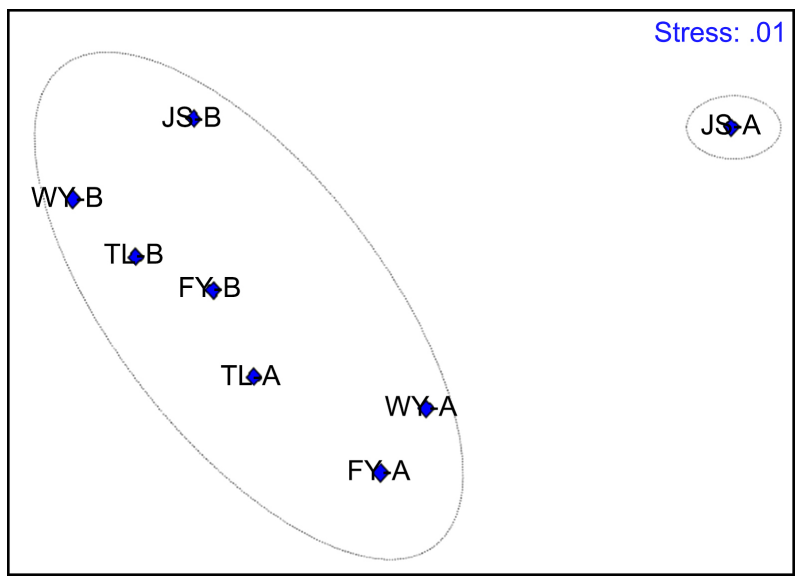

(b)

Figure 4. Cluster analysis of microplankton community on eight sampling sites based on metabarcoding monitoring. (a) Cluster analysis taken by group average method; (b) Non-metric multidimensional scaling ordination based on Bray-Curtis similarity of microplankton class composition.

\subsection{Data of High-Throughput Sequencing (HTS) and Morphology Comparison}

We compared the communities of phytoplankton and zooplankton taxa with results obtained from morphological analysis in order to determine potential biases of the primer set used in our study. Species of three phylum and five classes of eukaryotic phytoplankton were annotated by metabarcoding method, which was different from that identified by microscopic examination. Also, more than 104 phytoplankton species were identified by metabarcoding (193 species vs. 89 species) (Table 3). Chlorophyceae was the most common assemblage, which was consistent with the finding via morphology, accounting for $12.93 \%-79.45 \%$ of the total eukaryotic phytoplankton reads, among which Chlamydomonas reinhardtii was dominant, contributing $1.22 \%$ of the total reads. Meanwhile, genera with higher reads proportion, such as Chlamydomonas, Chlorella, Crucigenia, Cryptomonas, Actinastrum, Gonium and Dictyosphaerium, were widespread in freshwater of Zhejiang province [27] [28] and were also dominant genera that identified via morphology (Table S1). 
Table 3. Comparison analysis of eukaryotic phytoplankton data based on metabarcoding technology and morphological examination.

\begin{tabular}{ccc}
\hline Description & Metabarcoding monitoring & Morphological monitoring \\
\hline Number of phylum & 3 & 5 \\
Phylum list & $\begin{array}{c}\text { Chlorophyta, Bacillariophyta } \\
\text { and Cryptophyta }\end{array}$ & $\begin{array}{c}\text { Chlorophyta, Bacillariophyta, } \\
\text { Cryptophyta, Euglenophyta } \\
\text { and Dinoflagellate }\end{array}$ \\
Number of classes & 5 & 6 \\
Classes list & $\begin{array}{c}\text { Pedinophyceae, Chlorophyceae, } \\
\text { Trebouxiophyceae, Centricae } \\
\text { and Cryptophyceae }\end{array}$ & $\begin{array}{c}\text { Chlorophyceae, Centricae, Pennatae, } \\
\text { Cryptophyceae, uglenophyceae } \\
\text { and Dinophyceae }\end{array}$ \\
Number of genus & 99 & 50 \\
Number of species & 193 & 89 \\
\hline
\end{tabular}

For the zooplankton, the comparisons were made with data reported by [29] and [30]. As a widely distributed taxa in Qiantang River, Cyclopoida was identified in this study, and the dominant species of Cyclopoida annotated on were Mesocyclops leuckarti and Acanthocyclops bicuspidatus, which was consistent with the discovery of [29]. However, as another dominant assemblage [30], rotifers were not annotated here.

\section{Disscussion}

\subsection{The Feasibility of Microplankton Community Analysis Based on ITS Gene Metabarcoding}

In this study, we selected ITS with fast evolution and high specificity as the amplicon to describe the community structure and its dynamics of eukaryotic microplankton in Qiantang River lower reaches. Here, the community characteristics of fungi in the Qiantang River were first researched, it's found that Dothideomycetes, Sordariomycetes, Eurotiomycetes and Tremellomycetes were the most common groups, which were different from that in the Yellow Sea concluded by using the same amplicon [22].

After compared the communities of phytoplankton and zooplankton taxa with results obtained from metabarcoding and morphological analysis, we revealed the same most common assemblage, and discovered 104 more species via metabarcoding. Compared with previous studies [28], it's speculated that the phytoplankton community had changed somewhat since then, but some dominant specieses maintained unchanged, genera Chlamydomonas and Cryptophyllum were still common dominant groups. Meanwhlie, Anthoathecata, a zooplankton taxa that hasn't been identified by microscopic examination, was annotated on JS samples. Anthoathecata is an order of class Hydrozoa and distributes on the east and south coast of China. Here, JS sites are located in the estuary area of Qiantang River, indicating a possibility that species of Anthoa- 
thecata distribution. However, rotifers were not detected by metabarcoding. The predatory relationship between species may be a considerable reason. Generally, the DNA of the prey does not get separated out during the blast, especially if the prey items belong to the same genus as the predator. In addition, the preference of primer and differences in rRNA gene copy numbers may also explain some of these differences.

Overall, these findings demonstrated that metabarcoding could yield comparable results to conventional methods for several abundant eukaryotic taxa, but that each method has different limitations as far as accurately describing the eukaryotic composition in this river.

\subsection{Community Diversity Characteristic of Eukaryotic Microplankton}

Here, geographically, the sampling sites from top to bottom are, in order, Tonglu, Fuyang, Wenyan and Jiashao. There is no hydraulic dam between the four sampling sits, and all of them are in the tidal reach of the river, resulting in a relatively frequent water exchange caused by the flow of tide. Compared with other sites, JS is near estuarine region and more affected by seawater. Correlation analysis showed that there were significant spatial differences in values of Chao 1 index $(\mathrm{p}<0.05)$, indicating the species richness had obvious dissimilarity between sampling sites. Cluster analysis and NMDS ordination further confirmed the microplankton class composition of JS-A had the most dissimilarity with that of the other samples, the content of salinity might be one of the reasons [31]. Studies have shown that some spatial differences in eukaryotic plankton $\alpha$-diversity is more the result of selection by local environmental conditions than dispersal [32], the feasibility of $\alpha$-diversity based on ITS rRNA gene metabarcoding might be a useful indicator for discriminating ecological condition.

\section{Conclusion}

Our data were generated using a primer set that targets the ITS region of ribosomal RNA gene, a region that has been widely used in biodiversity assessments in phytoplankton, fungi, zooplankton, etc. As a result, various species of phytoplankton, fungi and zooplankton were annotated. We identified several groups of eukaryotic phytoplankton and zooplankton that were not described by morphological analysis, and increased research on fungi in Qiantang River that never had been studied before. Chlorophyceae was the most common assemblage both identified by using ITS gene metabarcoding and morphological examination methods, also Mesocyclops leuckarti and Acanthocyclops bicuspidatus were both found to be the dominant species of Cyclopoida in the river. The reads proportions of phytoplankton and zooplankton at the three freshwater sampling sites (Tonglu, Fuyang and Wenyan) decreased as temperature drop. In addition, there were significant spatial differences in values of Chao1 index for eukaryotic microplankton. Finally, it's confirmed that the Metabarcoding-based approach 
herein described can be used in analyzing community characteristics of eukaryotic microplankton to some extent and will significantly be complete as technology improved.

\section{Acknowledgements}

We would like to thank the sequencing staff of LC-BIO for their help in high-throughput sequencing. This research was provided by Zhejiang Science and Technology Project (No. 2019C02047) to Zhiming Zhou.

\section{Conflict of Interest}

The authors declare no conflicts of interest regarding the publication of this paper.

\section{References}

[1] Si Sieburth, J.M., Smetacek, V. and Lenz, J. (1978) Pelagic Ecosystem Structure: Heterotrophic Compartments of the Plankton and Their Relationship to Plankton Size Fractions. Limnology and Oceanography, 23, 1256-1263.

https://doi.org/10.4319/lo.1978.23.6.1256

[2] Lovejoy, C., Massana, R. and Pedrós-Alió, C. (2006) Diversity and Distribution of Marine Microbial Eukaryotes in the Arctic Ocean and Adjacent Seas. Applied and Environmental Microbiology, 72, 3085-3095. https://doi.org/10.1128/AEM.72.5.3085-3095.2006

[3] Jørgensen, S.E., Xu, L. and Costanza, R. (2016) Handbook of Ecological Indicators for Assessment of Ecosystem Health. 2nd Edition, CRC Press, New York, 464 p. https://doi.org/10.1201/EBK1439809365

[4] Chan, A., Chiang, L.P., Hapuarachchi, H.C., Tan, C.H., Pang, S.C., Lee, R., Lee, K.S., Ng, L.C. and Lam-Phua, S.G. (2014) DNA Barcoding: Complementing Morphological Identification of Mosquito Species in Singapore. Parasites and Vectors, 7, 569. https://doi.org/10.1186/s13071-014-0569-4

[5] Ko, H.L., Wang, Y.T., Chiu, T.S., Lee, M.A., Leu, M.Y., Chang, K.Z., Chen, W.Y. and Shao, K.T. (2013) Evaluating the Accuracy of Morphological Identification of Larval Fishes by Applying DNA Barcoding. PLOS ONE, 8, e53451.

https://doi.org/10.1371/journal.pone.0053451

[6] Pawlowski, J., Lejzerowicz, F., Apotheloz-Perret-Gentil, L., Visco, J. and Esling, P. (2016) Protist Metabarcoding and Environmental Biomonitoring: Time for Change. European Journal of Protistology, 55, 12-25. https://doi.org/10.1016/j.ejop.2016.02.003

[7] Trebitz, A.S., Hoffman, J.C., Darling, J.A., Pilgrim, E.M., Kelly, J.R., Brown, E.A., Chadderton, W.L., Egan, S.P., Grey, E.K., Hashsham, S.A., Klymus, K.E., Mahon, A.R., Ram, J.L., Schultz, M.T., Stepien, C.A. and Schardt, J.C. (2017) Early Detection Monitoring for Aquatic Non-Indigenous Species: Optimizing Surveillance, Incorporating Advanced Technologies, and Identifying Research Needs. Journal of Environmental Management, 202, 299-310. https://doi.org/10.1016/j.jenvman.2017.07.045

[8] Bell, T.A.S., Emel, S.K., Felföldi, T., Vasas, G., Fields, M.W. and Peyton, B.M. (2018) Microbial Community Changes during a Toxic Cyanobacterial Bloom in an Alkaline Hungarian Lake. Antonie van Leeuwenhoek, 111, 2425-2440. 
https://doi.org/10.1007/s10482-018-1132-7

[9] Keck, F., Vasselon, V., Tapolczai, K., Rimet, F. and Bouchez, A. (2017) Freshwater Biomonitoring in the Information Age. Frontiers in Ecology and the Environment, 15, 266-274. https://doi.org/10.1002/fee.1490

[10] Banerji, A., Bagley, M., Elk, M., Pilgrim, E., Martinson, J. and Santo Domingo, J. (2018) Spatial and Temporal Dynamics of a Freshwater Eukaryotic Plankton Community Revealed via 18s rRNA Gene Metabarcoding. Hydrobiologia, 818, 71-86. https://doi.org/10.1007/s10750-018-3593-0

[11] Cannon, M.V., Bogale, H., Rutt, L., Humphrys, M., Korpe, P., Duggal, P., Ravel, J. and Serre, D. (2018) A High-Throughput Sequencing Assay to Comprehensively Detect and Characterise Unicellular Eukaryotes and Helminths from Biological and Environmental Samples. Microbiome, 6, 195.

https://doi.org/10.1186/s40168-018-0581-6

[12] Matyugina, E., Belkova, N., Borzenko, S., Lukyanov, P., Kabilov, M., Baturina, O., Martynova-Van Kley, A., Nalian, A. and Ptitsyn, A. (2018) Structure and Diversity Dynamics of Microbial Communities at Day and Night: Investigation of Meromictic Lake Doroninskoe, Transbaikalia, Russia. Journal of Oceanology and Limnology, 36, 80-94. https://doi.org/10.1007/s00343-018-7332-1

[13] Wang, X.H., Wang, S.H. and Zhao, H. (2019) Unraveling Microbial Community Diversity and Succession of Chinese Sichuan Sausages during Spontaneous Fermentation by High-Throughput Sequencing. Journal of Food Science and Technology-Mysore, 56, 3254-3263. https://doi.org/10.1007/s13197-019-03781-y

[14] Stoddard, S.F., Smith, B.J., Hein, R., Roller, B.R.K. and Schmidt, T.M. (2014) rrnDB: Improved Tools for Interpreting rRNA Gene Abundance in Bacteria and Archaea and a New Foundation for Future Development. Nucleic Acids Research, 43, 593-598. https://doi.org/10.1093/nar/gku1201

[15] Capo, E., Domaizon, I., Maier, D., Debroas, D. and Bigler, C. (2017) To What Extent Is the DNA of Microbial Eukaryotes Modified during Burying into Lake Sediments? A Repeat-Coring Approach on Annually Laminated Sediments. Journal of Paleolimnology, 58, 479-495. https://doi.org/10.1007/s10933-017-0005-9

[16] Qiao, L., Yu, J., Li, Y., Guo, H.B., Zhen, Y., Zhang, L.I., Mi, T.Z., Bao, Z.M. and Xu, X.C. (2019) Amplicon-Based Illumina Sequencing and Quantitative PCR Reveals Nanoplankton Diversity and Biomass in Surface Water of Qinhuangdao Coastal Area, China. Journal of Ocean University of China, 18, 962-976. https://doi.org/10.1007/s11802-019-3774-0

[17] Saunders, G.W. and Kucera, H. (2010) An Evaluation of rbc L, tuf A, UPA, LSU and ITS as DNA Barcode Markers for the Marine Green Macroalgae. Cryptogamie Algologie, 31, 487-528.

[18] Song, L., Wu, J., Du, J., Li, N., Song, G.J., Wang, K., Sun, M. and Wang, P. (2019) The Characteristics and Distribution of Eukaryotic Phytoplankton Community in Liaodong Bay, China. Ocean Science Journal, 54, 183-203.

https://doi.org/10.1007/s12601-019-0007-9

[19] Geml, J., Gravendeel, B., van der Gaag, K.J., Neilen, M., Lammers, Y., Raes, N., Semenova, T.A., de Knijff, P. and Noordeloos, M.E. (2014) The Contribution of DNA Metabarcoding to Fungal Conservation: Diversity Assessment, Habitat Partitioning and Mapping Red-Listed Fungi in Protected Coastal Salix Repens Communities in the Netherlands. PLoS ONE, 9, e99852.

https://doi.org/10.1371/journal.pone.0099852

[20] Li, Y.L., Dong, J., Wang, B., Sun, M., Wang, A.Y. and Wang, W.B. (2016) Molecular 
Identification and Detection of Cyanea nozakii by Partial Sequencing of $18 \mathrm{~S}$ rDNA and Its-5.8S. Oceanologia Et Limnologia Sinica, 47, 158-165.

[21] Zhang, T. and Yao, Y.F. (2015) Endophytic Fungal Communities Associated with Vascular Plants in the High Arctic Zone Are Highly Diverse and Host-Plant Specific. PLoS ONE, 10, e0130051. https://doi.org/10.1371/journal.pone.0130051

[22] Zhang, L., Lin, J.N., Zhang, Y., Wang, S.P. and Zhang, X.J. (2018) Eukaryotic Microplankton Community Diversity and Characteristics of Regional Distribution in the Yellow Sea by ITS High-Throughput Sequencing. Environmental Science, 39, 400-411.

[23] Lv, H., Yang, J., Liu, L.M., Yu, X.Q., Zheng, Y. and Chiang, P.C. (2014) Temperature and Nutrients Are Significant Drivers of Seasonal Shift in Phytoplankton Community from a Drinking Water Reservoir, Subtropical China. Environmental Science and Pollution Research, 21, 5917-5928.

https://doi.org/10.1007/s11356-014-2534-3

[24] Cock, P.J., Antao, T., Chang, J.T., Chapman, B.A., Cox, C.J., Dalke, A., Friedberg, I., Hamelryck, T., Kauff, F. and Wilczynski, B. (2009) Biopython: Freely Available Python Tools for Computational Molecular Biology and Bioinformatics. Bioinformatics, 25, 1422-1423. https://doi.org/10.1093/bioinformatics/btp163

[25] Edgar, R.C. (2010) Search and Clustering Orders of Magnitude Faster than BLAST. Bioinformatics, 26, 2460-2461. https://doi.org/10.1093/bioinformatics/btq461

[26] Clarke, K.R. and Warwick, R.M. (2001) Changes in Marine Communities: An Approach to Statistical Analysis and Interpretation. Mount Sinai Journal of Medicine New York, 40, 689-692.

[27] Zhang, A.J., Liu, J.D., Yang, Y.J., Guo, A.H. and Zhao, Z.Y. (2016) The Analysis of the Community Characteristics of Macrozoobenthos in Enhancement and Releasing Zone of Qiantang River, Tonglu Section. Acta Agriculturae Zhejiangensis, 28, 1323-1331.

[28] Xia, W.C., Xie, L.N., Tong, Y.Y. and Ma, X.N. (1989) Investigation on Resources of Main Economic Fish and Food Organism in the Qiantang River Lower Reaches. Reservoir Fisheries, 2, 32-35.

[29] Yu, J., Yu, H.Y. and Yao, J.L. (2010) Distribution and Seasonal Changes of Crustacean Plankton in Qiantang River Basin. Notification of Marine Lakes, 4, 61-71.

[30] Guo, A.H., Yuan, J.L., Zhang, A.J., Hao, Y.B., Liu, J.D. and Gu, Z.M. (2019) The Spatial and Temporal Pattern of Rotifer Community in Fuchun Section of Qiantang River and Its Relationship with Environmental Factors. Jiangsu Agricultural Science, 47, 243-247.

[31] Cui, S.K., He, J.F., He, P.M., Zhang, F., Lin, L. and Ma, Y.X. (2014) Adaptation of Phytoplankton Communities to Light and Salinity Variation in Kongsfjorden (Spitsbergen), Arctic. Chinese Journal of Polar Research, 26, 230-237.

[32] Havel, J.E. and Shurin, J.B. (2004) Mechanisms, Effects, and Scales of Dispersal in Freshwater Zooplankton. Limnology and Oceanography, 49, 1229-1238.

https://doi.org/10.4319/lo.2004.49.4_part_2.1229 


\section{Supplementary Information}

Supplementary information accompanies this paper at:

https://doi.org/10.4236/ojas.2021.111009

Additional file 1: Figure S1. Results of eight water DNA samples amplified by the ITS primer. Table S1. Species of eukaryotic phytoplankton indentified by using ITS gene metabarcoding technology and morphological examination.

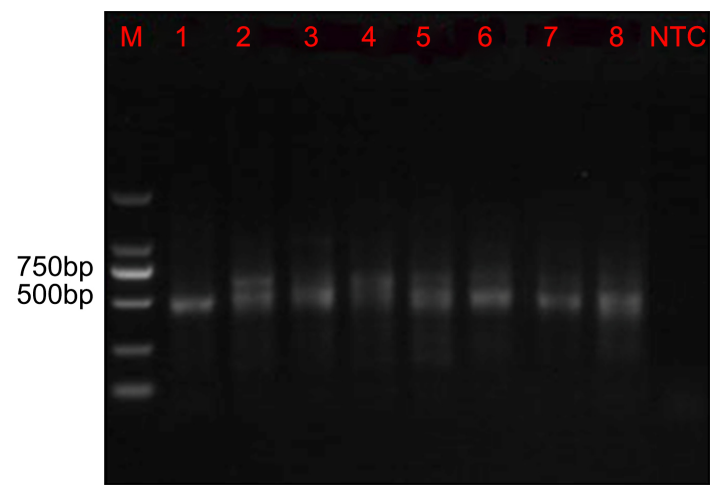

Figure S1. Results of eight water DNA samples amplified by the ITS primer. Lane M: Takara DL2000 DNA Maker; Lane 1 to 8: PCR products of JS-A, WY-A, FY-A, TL-A, JS-B, WY-B, FY-B and TL-B; Lane NTC: Negative control.

Table S1. Species of eukaryotic phytoplankton indentified by using ITS gene metabarcoding technology and morphological method.

\begin{tabular}{|c|c|c|c|c|}
\hline \multirow{2}{*}{ Number } & \multicolumn{2}{|c|}{ Metabarcoding monitoring } & \multicolumn{2}{|c|}{ Morphological monitoring } \\
\hline & Classes & Species & Classes & Species \\
\hline 1 & Chlorophyta & Pedinomonas sp. & Chlorophyta & Cosmarium sp. \\
\hline 2 & & Acutodesmus bajacalifornicus & & Cosmarium abbreviatum \\
\hline 3 & & Acutodesmus deserticola & & Cosmarium circulare \\
\hline 4 & & Acutodesmus sp. KNUA038 & & Cosmarium leave \\
\hline 5 & & Coelastrella rubescens & & Cosmarium absoletum \\
\hline 6 & & Coelastrella vacuolata & & Euastrum dubium \\
\hline 7 & & Coelastrella sp. & & Penium Cruciferum \\
\hline 8 & & Coronastrum ellipsoideum & & Closterium sp. \\
\hline 9 & & Nephrochlamys subsolitaria & & Pleodorina sp. \\
\hline 10 & & Planktosphaeria gelatinosa & & Tetraedron minimum \\
\hline 11 & & Desmodesmus armatus & & Tetraspora sp. \\
\hline 12 & & Desmodesmus asymmetricus & & Raphidonema sp. \\
\hline 13 & & Desmodesmus bicellularis & & Chlamydomonas sp. \\
\hline 14 & & Desmodesmus brasiliensis & & Platymonas elliptica \\
\hline 15 & & Desmodesmus communis & & Coelastrum microporum \\
\hline 16 & & Desmodesmus costato-granulatus & & Eudorina sp. \\
\hline
\end{tabular}




\section{Continued}

Desmodesmus denticulatus

Desmodesmus insignis

Desmodesmus intermedius

Desmodesmus maximus

Desmodesmus opoliensis

Desmodesmus pannonicus

Desmodesmus perdix

Desmodesmus pirkollei

Desmodesmus santosii

Desmodesmus sp.

Hariotina reticulata

Pectinodesmus pectinatus

Pectinodesmus regularis

Sphaeroplea robusta

Rotundella rotunda

Monoraphidium griffithii

Tetradesmus acuminatus

Tetradesmus bernardii

Tetradesmus distendus

Tetradesmus incrassatulus

Tetradesmus nygaardii

Tetradesmus obliquus

Tetradesmus reginae

Verrucodesmus parvus

Neochloris conjuncta

Neochloris vigensis

Neochloris sp. AY2

Stauridium privum

Stauridium tetras

Lacunastrum gracillimum

Monactinus sturmii

Hydrodictyon reticulatum

Pseudopediastrum sp. KNUA039

Chlamydomonas applanata

Chlamydomonas asymmetrica

Pandorina sp.

Schroederia spiralis

Chlorella sp.

Actinastrum sp.

Ankistrodesmus angustus

Ankistrodesmus convolutus

Ankistrodesmus falcatus

Ankistrodesmus falcatus var.mirabilis

Oocystis lacustris

Pediastrum simplex

Pediastrum tetras

Crucigenia quadrata

Crucigenia apiculata

Scenedesmus sp.

Scenedesmus bijuga

Scenedesmus quadricauda

Bacillariophyta

Cyclotella sp.

Cyclotella meneghiniana

Cyclotella aslerocastata

Melosira granulata

Melosira granulate

Melosira granulata var. angustissima

Melosira varians

Coscinodiscus sp.

Coscinodiscus subtilis

Coscinodiscus oculusiridis

Skeletonema costatum

Synedra acus

Synedra ulna

Synedra ulna var. impressa

Fragilaria sp.

Fragilaria capucina

Fragilaria biceps

Gomphonema sp.

Gomphonema subclavatum 


\section{Continued}

\begin{tabular}{|c|c|c|c|}
\hline 52 & Chlamydomonas bacca & & Gomphonema simus \\
\hline 53 & Chlamydomonas debaryana & & Gomphonema parvulum \\
\hline 54 & Chlamydomonas dorsoventralis & & Cocconeis placentula \\
\hline 55 & Chlamydomonas globosa & & Nitzschia sp. \\
\hline 56 & Chlamydomonas hedleyi & & Nitzschia acula \\
\hline 57 & Chlamydomonas inflexa & & Nitzschia palea \\
\hline 58 & Chlamydomonas leiostraca & & Nitzschia acicularis \\
\hline 59 & Chlamydomonas mexicana & & Surirella ovata \\
\hline 60 & Chlamydomonas proboscigera & & Surirella robusta \\
\hline 61 & Chlamydomonas rapa & & Gyrosigma acuminatum \\
\hline 62 & Chlamydomonas reinhardtii & & Didymosphenia geminata \\
\hline 63 & Chlamydomonas sphagnophila & & Amphoraovalis \\
\hline 64 & Chlamydomonas splendida & & Frustulia vulgaris \\
\hline 65 & Chlamydomonas sp. & & Navicula sp. \\
\hline 66 & Gloeomonas anomalipyrenoides & & Navicula rhynchocephala \\
\hline 67 & Lobochlamys segnis & & Navicula cuspidata \\
\hline 68 & Chloromonas perforata & & Cymbella sp. \\
\hline 69 & Carteria eugametos & & Cymbellalanceolata \\
\hline 70 & Carteria incisa & & Cymbellaturgidula \\
\hline 71 & Tetraselmis suecica & & Diatoma vulgare \\
\hline 72 & Vitreochlamys nekrassovii & & Eunotia sp. \\
\hline 73 & Colemanosphaera charkowiensis & & Pinnularia sp. \\
\hline 74 & Volvulina compacta & & Cymatopleura sp. \\
\hline 75 & Gonium pectorale & & Cymatopleura elliptica \\
\hline 76 & Coelastrum astroideum & & Leptocylindrus danicus \\
\hline 77 & Coelastrum microporum & & Trioeratium favm \\
\hline 78 & Coelastrum pseudomicroporum & Cryptophyta & Cryptomonas ovata \\
\hline 79 & Eudorina cylindrica & & Cryptomonas erosa \\
\hline 80 & Eudorina elegans & & Chroomonas caudata \\
\hline 81 & Eudorina sp. KMMCC 1278 & Euglenophyta & Euglena sp. \\
\hline 82 & Eudorina unicocca & & Euglena geniculata \\
\hline 83 & Pandorina colemaniae & & Trachelomonas curta \\
\hline 84 & Pandorina morum & & Strombomonas fluviatilis \\
\hline 85 & Volvox carteri & Pyrrophyta & Peridinium sp. \\
\hline 86 & Dunaliella parva & & Peridinium pusillum \\
\hline
\end{tabular}


A. J. Zhang et al.

\section{Continued}

87

88

89

90

91

92

93

94

95

96

97

98

99

100

101

102

103

104

105

106

107

108

109

110

111

112

113

114

115

116

117

118

119

120

121
Dunaliella pseudosalina

Characium oviforme

Schroederia setigera

Closteriopsis acicularis

Didymogenes anomala

Didymogenes palatina

Kalenjinia gelatinosa

Marasphaerium gattermannii

Marvania geminata

Masaia oloidia

Meyerella planktonica

Graesiella emersonii

Pseudochlorella signiensis

Nannochloris sp. AICB 424

Compactochlorella dohrmannii

Compactochlorella kochii

Chlorella miniata

Chlorella pulchelloides

Chlorella sorokiniana

Chlorella sp.

Actinastrum hantzschii

Selenastrum capricornutum

Kirchneriella aperta

Kirchneriella lunaris

Ankistrodesmus falcatus

Ankyra judayi

Chlorococcum oleofaciens

Chlorococcum sp. CCAP 11/52

Micractinium belenophorum

Micractinium inermum

Micractinium reisseri

Micractinium sp.

Neospongiococcum sp. SAG 2474

Coenochloris sp. KR 2006/325

Franceia amphitricha
Peridinium umbonatum

Ceratium hirundinella

Gymnodinium sp. 


\section{Continued}

\begin{tabular}{|c|c|}
\hline 122 & Oocystella oogama \\
\hline 123 & Oocystis sp. KMMCC 251 \\
\hline 124 & Pediastrum duplex \\
\hline 125 & Pedinomonas minor \\
\hline 126 & Crucigenia lauterbornii \\
\hline 127 & Westella botryoides \\
\hline 128 & Scenedesmus armatus \\
\hline 129 & Scenedesmus bijugus \\
\hline 130 & Scenedesmus quadricauda \\
\hline 131 & Scenedesmus sp. \\
\hline 132 & Dictyosphaerium ehrenbergianum \\
\hline 133 & Dictyosphaerium lacustre \\
\hline 134 & Dictyosphaerium libertatis \\
\hline 135 & Dictyosphaerium sp. \\
\hline 136 & Sorastrum pediastriforme \\
\hline 137 & Oedogonium angustistomum \\
\hline 138 & Oedogonium cardiacum \\
\hline 139 & Oedogonium cylindrosporum \\
\hline 140 & Oedogonium donnellii \\
\hline 141 & Oedogonium subdissimile \\
\hline 142 & Oedogonium tenerum \\
\hline 143 & Oedogonium undulatum \\
\hline 144 & Oedogonium sp. \\
\hline 145 & Gloeotilopsis planctonica \\
\hline 146 & Chamaetrichon basiliensis \\
\hline 147 & Uronema sp. AF-2012 \\
\hline 148 & Uronema sp. CCAP 334/1 \\
\hline 149 & Uronema sp. CCAP 335/1B \\
\hline 150 & Urospora neglecta \\
\hline 151 & Chaetopeltis orbicularis \\
\hline 152 & Chaetophora sp. BEA 0173B \\
\hline 153 & Hormotilopsis gelatinosa \\
\hline 154 & Hormotilopsis tetravacuolaris \\
\hline 155 & Draparnaldia plumosa \\
\hline 156 & Stigeoclonium helveticum \\
\hline 157 & Schizomeris leibleinii \\
\hline
\end{tabular}


A. J. Zhang et al.

\section{Continued}

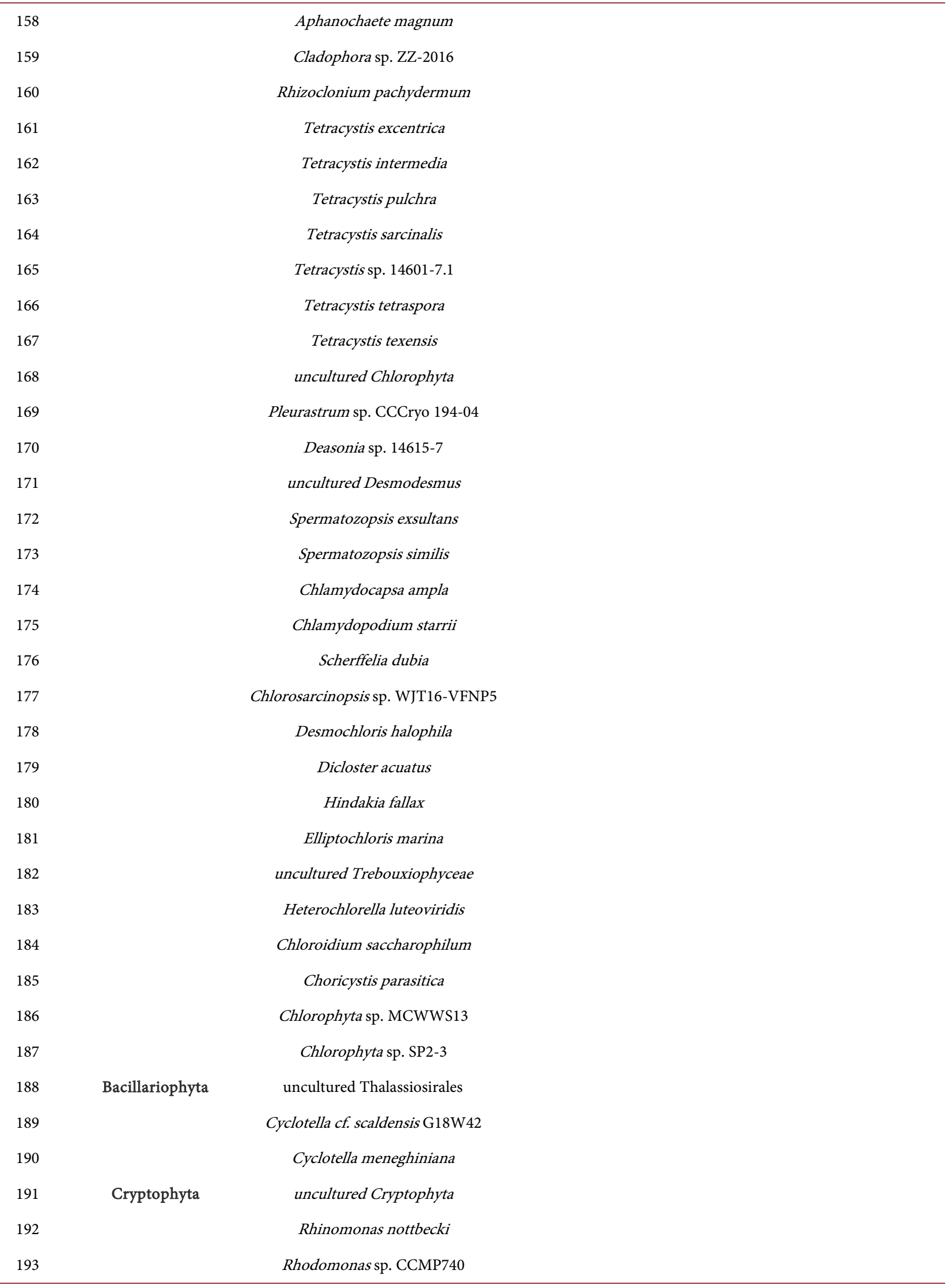

